\title{
PENERAPAN MODEL UTAUT 2 UNTUK MEMAHAMI PERILAKU PENGGUNAAN OASIS DI SEKOLAH TINGGI TEKNOLOGI BANDUNG
}

\author{
Fadila Andini ${ }^{1}$, Ifani Hariyanti ${ }^{2}$ \\ Program Studi Sistem Informasi ${ }^{1,2}$ \\ Universitas Adhirajasa Reswara Sanjaya ${ }^{1,2}$ \\ fadilaandini1@gmail.com ${ }^{1}$,ifani@ ars.ac.id²
}

\begin{abstract}
Abstrak
OASIS (Online Academics Information System) merupakan suatu Sistem Informasi Akademik yang dirancang untuk memberikan kemudahan bagi mahasiswa untuk memperoleh informasi tanpa harus melakukan interaksi langsung dengan bagian administrasi karena informasi tersebut dapat diperoleh dengan melakukan pencarian data melalui komputer yang terkoneksi secara internet seperti proses pengisian Kartu Rencana Studi (KRS), pengajuan surat penelitian, informasi pembimbing Skripsi dan yang lainnya. Salah satu faktor penentu keberhasilan penerapan teknologi informasi adalah sikap pengguna yang memanfaatkan teknologi tersebut. Penelitian ini dilakukan untuk mengetaui faktor-faktor yang mempengaruhi perilaku pengguna OASIS dengan penerapan model UTAUT 2 di Sekolah Tinggi Teknologi Bandung. Tujuh konstruk dari UTAUT 2 digunakan sebagai determinan yang mempengaruhi perilaku pengguna (use behavior), yaitu: performance expectancy, effort expectancy, social influence dan facilitating conditions, hedonic motivation, price value, habit. Data dikumpulkan melalui kuesioner yang disebarkan kepada mahasiswa. Data diolah dan dianalisis dengan teknik regresi linier berganda menggunakan SPSS 25. Hasil yang diperoleh dari penelitian ini adalah variabel performance expectancy, effort expectancy berpengaruh signifikan sedangkan variabel social influence dan facilitating conditions, hedonic motivation, price value, habit tidak berpengaruh signifikan. Tingkat hubungan semua variabel dengan perilaku pengguna memiliki hubungan yang signifikan dengan nilai f hitung 11,840 nilai sig 0,000 dan nilai R Square 0,474 atau 47,4\%.
\end{abstract}

Kata kunci: Sistem Informasi Akademik, OASIS, UTAUT 2, SPSS25

\begin{abstract}
OASIS (Online Academics Information System) is an Academic Information System designed to provide convenience for students to obtain information without having to interact directly with the administration because this information can be obtained by searching for data through a computer connected to the internet such as the process of filling out a Plan Card. Study (KRS), submission of research letters, thesis supervisor information and others. One of the determining factors for the successful application of information technology is the attitude of users who use the technology. This research was conducted to determine the factors that influence the behavior of OASIS users with the application of the UTAUT 2 model at Sekolah Tinggi Teknologi Bandung. Seven constructs from UTAUT 2 are used as determinants that influence use behavior, namely: performance expectancy, effort expectancy, social influence and facilitating conditions, hedonic motivation, price value, habit. Data were collected through questionnaires distributed to students. The data were processed and analyzed using multiple linear regression using SPSS 25. The results from this study are that the variables of performance expectancy, effort expectancy have a significant effect, while the variables of social influence and facilitating conditions, hedonic motivation, price value, habit have no significant effect. The level of relationship of all variables with user behavior has a significant relationship with the calculated $f$ value of 11,840 , sig value of 0.000 and $R$ Square value of 0.474 or $47.4 \%$.
\end{abstract}

Keywords: Academic Information System, OASIS, UTAUT 2, SPSS25

\section{PENDAHULUAN}

Kebutuhan akan penggunaan teknologi saat ini sudah menjadi hal yang sangat umum dimasyarakat. Apalagi dengan adanya pandemi covid yang belum mereda sampai saat ini membuat segala urusan mulai dari pekerjaan dan kegiatan belajar mengajar semua menggunakan teknologi [3]. Dengan hadirnya teknologi informasi memberi pengaruh terhadap perilaku pengguna teknologi tersebut. Salah satu faktor yang mempengaruhi tingkat keberhasilan penerapan teknologi adalah perilaku pengguna [5].

Faktor yang memegang peranan penting dalam keberhasilan penerapan teknologi informasi salah satunya adalah faktor pengguna. Pengguna salah satu aspek yang penting untuk diperhatikan dalam penerapan TIK. Kesiapan pengguna untuk menerima teknologi tersebut mempunyai pengaruh besar dalam menentukan sukses atau tidak nya penerapan teknologi tersebut [6].

Perilaku pengguna terbentuk dari sikap dan persepsi pengguna terhadap teknologi informasi tersebut. Salah satu upaya untuk memahami perilaku pengguna teknologi informasi adalah melalui kajian dan penelitian terhadap teori atau model adopsi teknologi informasi [12]. Sistem yang baik adalah sistem yang mudah digunakan (user friendly). Kepuasan pengguna merupakan sikap individu terhadap sistem informasi, yang dapat mempengaruhi individu tersebut untuk menggunakan teknologi secara terus-menerus [5].

Saat ini banyak organisasi yang menerapkan sistem teknologi informasi modern dan canggih dengan biaya tinggi, akan tetapi permasalahan yang timbul adalah masih rendahnya penggunaan sistem informasi secara berkesinambungan [13]. Sistem informasi akan membantu organisasi ataupun mahasiswa untuk menyajikan informasi secara cepat, akurat dan terbuka seperti yang diharapkan oleh masyarakat. Masyarakat saat ini mempunyai pemikiran maju yang lambat laun akan meninggalkan cara-cara manual dan membuat terobosan baru untuk mendapatkan informasi. Begitupun di dalam perkuliahan, sistem informasi akan sangat berguna untuk proses belajar dan mengajar antara mahasiswa dan dosen [2]. 
Sistem Informasi Akademik merupakan sebuah sistem yang digunakan oleh institusi pendidikan yang dimanfaatkan untuk meningkatkan pelayanan kepada mahasiswanya. Sistem informasi akademik ini mempunyai banyak sekali manfaat bagi institusi dalam bidang pendidikan, baik itu dalam pengolahan data pengajaran, data nilai, dan data-data lainnya yang terkait dengan akademik pembelajaran dalam hal ini khususnya perguruan tinggi [10].

UTAUT dikembangkan dari Technology Acceptance Model (TAM) pada tahun 2003 dengan empat konstruk yang mempengaruhi niat perilaku untuk menggunakan teknologi yaitu: performance expectancy, effort expectancy, social influence, facilitating conditions. Sampai saat ini UTAUT sudah dikembangkan kembali dari konteks organisasi menjadi konteks konsumen individu yang diberi nama Model UTAUT 2 di mana habit, hedonic motivation dan price value ditambahkan sebagai konstruksi baru [9].

Sekolah Tinggi Teknologi Bandung (STTB) merupakan sebuah sekolah tinggi yang beralamat di Jl. Soekarno Hatta No. 378 Bandung. STTB berdiri sejak tahun 1991, memiliki 3 Program Studi, yaitu Teknik Industri, Teknik Informatika dan Desain Komunikasi Visual. Pada awal penerapan OASIS (Online Academics Information System), ditemukan beberapa perbedaan kebiasaan dalam pemanfaatan teknologi informasi. Diharapkan model UTAUT 2 dalam penelitian ini dapat digunakan untuk menjelaskan perilaku pengguna OASIS (Online Academics Information System) di STTB.

\section{TINJAUAN PUSTAKA}

\section{Sistem Informasi}

Sistem adalah kumpulan orang yang saling bekerja sama dengan ketentuan-ketentuan aturan yang sistematis dan terstruktur untuk membentuk suatu kesatuan yang melaksanakan suatu fungsi untuk mencapai tujuan. Sedangkan informasi adalah data yang diolah menjadi lebih berguna dan berarti bagi penerimanya, serta untuk mengurangi ketidakpastian dalam proses pengambilan keputusan mengenai suatu keadaan [1].

Sistem informasi merupakan kombinasi teratur dari manusia, hardware, software, jaringan komunikasi, dan sumber daya data, yang mengumpulkan mengubah, dan menyebarkan informasi dalam suatu organisasi untuk mendukung pembuatan keputusan dan mengontrol organisasi [7].

Berdasarkan pengertian-pengertian di atas, maka dapat disimpulkan bahwa sistem informasi adalah sekumpulan prosedur organisasi yang dilaksanakan untuk mencapai suatu tujuan yaitu memberikan informasi bagi pengambil keputusan dan untuk mengendalikan organisasi.

\section{Sistem Informasi Akademik}

Sistem informasi akademik merupakan salah satu sarana-prasarana yang ada di perguruan tinggi untuk memperoleh informasi bagi civitas akademika. Sarana merupakan segala sesuatu yang mendukung secara langsung terhadap kelancaran proses pembelajaran, sedangkan prasarana merupakan segala sesuatu yang secara tidak langsung dapat mendukung keberhasilan proses pembelajaran [2].

\section{Definisi Model UTAUT}

Model UTAUT menunjukan bahwa niat untuk berperilaku (behavioral intention) dan perilaku untuk menggunakan suatu teknologi (use behavior) dipengaruhi oleh harapan akan kinerja (performance expectancy), harapan akan usaha (effort expectancy), pengaruh sosial (social influence), dan kondisi pendukung (facilitating conditions) [12]. Diketahui pula terdapat empat variabel moderator yang memiliki pengaruh signifikan, yaitu Experience, Voluntariness of Use, Gender, dan Age [2].

Model UTAUT kemudian dikembangkan menjadi model UTAUT 2 pada tahun 2012 oleh Venkatesh, Thong, dan Xu. Venkatesh et al. (2012) menambahkan tiga variabel baru ke dalam model UTAUT, yaitu Hedonic Motivation, Price Value, dan Habit dan menyertakan tiga variabel moderator, yaitu Age, Gender, dan Experience. Menurut Venkatesh et.al. (2012) tiga variabel utama yang ditambahkan yaitu Hedonic Motivation, Price Value, dan Habit dapat menjelaskan secara langsung perilaku konsumen dalam penggunaan teknologi [2]. Pemodelan UTAUT 2 dapat dilihat pada Gambar II.1. berikut:

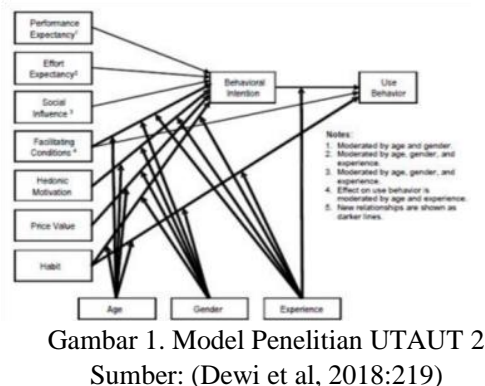

Alasan dari penambahan tiga konstruk utama tersebut adalah (1) Hedonic Motivation merupakan prediktor kunci dalam banyak penelitian mengenai perilaku konsumen dalam konteks penggunaan teknologi oleh konsumen; (2) Price Value dikarenakan konsumen akan mengeluarkan biaya dalam penggunaan teknologi yang dianggap sesuai 
dengan manfaat yang diberikan; dan (3) Habit yang telah terbukti sebagai faktor yang dapat memprediksi kebiasaan dalam penggunaan teknologi. Berikut penjelasan variabel-variabel yang terdapat pada model UTAUT 2 [8]:

a. Minat Pemanfaatan (Behavioral Intention)

Minat pemanfaatan teknologi informasi (behavioral intention) didefinisikan sebagai tingkat keinginan atau niat pemakai menggunakan sistem secara terus menerus dengan asumsi bahwa mereka mempunyai akses terhadap informasi. Seorang akan berminat menggunakan suatu teknologi informasi yang baru apabila si pengguna tersebut meyakini dengan menggunakan teknologi informasi tersebut akan meningkatkan kinerjanya, menggunakan teknologi informasi dapat dilakukan dengan mudah, dan si pengguna tersebut mendapatkan pengaruh lingkungan sekitarnya dalam menggunakan teknologi informasi tersebut [8].

b. Perilaku Penggunaan (Use Behavior)

Perilaku penggunaan teknologi informasi (use behavior) didefinisikan sebagai intensitas dan atau frekuensi pemakai dalam menggunakan teknologi informasi. Perilaku penggunaan teknologi informasi sangat bergantung pada evaluasi pengguna dari sistem tersebut. Suatu teknologi informasi akan digunakan apabila pemakai teknologi informasi tersebut berminat dalam menggunakan teknologi informasi tersebut karena keyakinan bahwa menggunakan teknologi informasi tersebut dapat meningkatkan kinerjanya, menggunakan teknologi informasi dapat dilakukan dengan mudah, dan pengaruh lingkungan sekitarnya dalam menggunakan teknologi informasi tersebut [8].

c. Ekspektasi Kinerja (Performance Expectancy)

Ekspektasi kinerja adalah sejauh mana seseorang percaya bahwa dengan menggunakan sistem akan membantu dia untuk mencapai keuntungan dalam kinerja pekerjaannya. Ekspektasi kinerja merupakan konstraksi yang kuat atas niat menggunakan sehingga dapat disimpulkan bahwa seseorang yang telah percaya sebuah sistem informasi dapat membantu pekerjaannya akan cenderung menggunakan sistem tersebut dalam waktu yang lebih lama. Dalam konsep ini terdapat gabungan variabel-variabel yang diperoleh dari model penelitian sebelumnya tentang model penerimaan dan penggunaan teknologi [8].

d. Ekspektasi Usaha (Effort Expectancy)

Ekspektasi usaha merupakan tingkat kemudahan terkait dalam pengguna sistem. Penggunaan teknologi informasi yang mudah dapat menimbulkan persepsi bahwa sistem itu berguna baginya dan menimbulkan kenyamanan bila menggunakannya. Namun jika sistem ini dirasa sulit untuk digunakan maka rasa nyaman bekerja dengan sistem tidak akan muncul dan niat menggunakan untuk memanfaatkan sistem akan berkurang [8].

e. Faktor Sosial (Social Influence)

Pengaruh sosial mempunyai dampak pada perilaku individual melalui tiga mekanisme yaitu ketaatan (compliance), internalisasi (internalization), dan identifikasi (identification). Dapat disimpulkan bahwa semakin banyak pengaruh yang diberikan sebuah lingkungan terhadap calon pengguna teknologi informasi untuk menggunakan suatu teknologi informasi yang baru maka semakin besar minat yang timbul dari personal calon pengguna tersebut dalam menggunakan teknologi informasi tersebut karena pengaruh yang kuat dari lingkungan sekitarnya [8].

f. Kondisi yang Memfasilitasi (Facilitating Conditions)

Facilitating Conditions merupakan variabel yang memiliki pengaruh langsung terhadap penggunaan sistem dan juga didefinisikan sebagai "sejauh mana seseorang percaya bahwa infrastruktur organisasi dan teknis dapat mendukung penggunaan sistem". Menurut Morris et al (2005) dalam Onibala et al (2021) Secara umum pengguna dengan tingkat kondisi yang memfasilitasi lebih rendah akan memiliki niat yang lebih rendah untuk menggunakan suatu teknologi. Dampak kondisi yang memfasilitasi tersebut dimoderasi oleh usia, jenis kelamin, dan pengalaman. Konsumen yang memiliki usia lebih tua cenderung menghadapi lebih banyak kesulitan dalam memproses informasi baru [8].

g. Motivasi Hedonis (Hedonic Motivation)

Motivasi hedonis (hedonic motivation) merupakan hal yang menyenangkan kesenangan yang berasal dari penggunaan teknologi, dan telah terbukti memainkan peran penting dalam menentukan penerimaan dan penggunaan teknologi. Dalam konteks konsumen, Hedonic Motivation juga telah ditemukan sebagai penentu penting penerimaan dan penggunaan teknologi. Dengan demikian, kita menambahkan Hedonic Motivation sebagai prediktor perilaku konsumen untuk menggunakan teknologi [8].

h. Nilai Harga (Price Value)

Struktur biaya dan harga mungkin berpengaruh signifikan terhadap penggunaan teknologi konsumen. Price Value dikatakan positif jika manfaat dalam menggunakan teknologi dirasakan lebih oleh pengguna dibandingkan biaya yang dikeluarkan, dan nilai harga juga memiliki pengaruh positif terhadap niat. Maka dari itu nilai harga dapat digunakan untuk menjadi prediktor dari variabel niat perilaku dalam menggunakan teknologi [11]. Perbedaan penting antara pengaturan penggunaan konsumen dan pengaturan penggunaan organisasi, dimana UTAUT dikembangkan, adalah bahwa konsumen biasanya menanggung biaya moneter untuk penggunaan tersebut sedangkan karyawan tidak. Struktur biaya dan harga mungkin berpengaruh signifikan terhadap penggunaan teknologi konsumen [11]. 
i. $\quad$ Kebiasaan (Habit)

Konstruk terakhir yang ditambahkan ke UTAUT adalah Habit. Pengalaman yang dioperasikan sebagai tiga tingkat berdasarkan berlalunya waktu: (1) pasca pelatihan adalah saat sistem awalnya tersedia untuk digunakan; (2) satu bulan kemudian; (3) tiga bulan kemudian [8].

\section{METODE PENELITIAN}

Metode penelitian yang dilakukan oleh peneliti yaitu langkah-langkah yang dilaksanakan pada hal-hal yang berhubungan dengan penelitian adalah sebagai berikut ini:

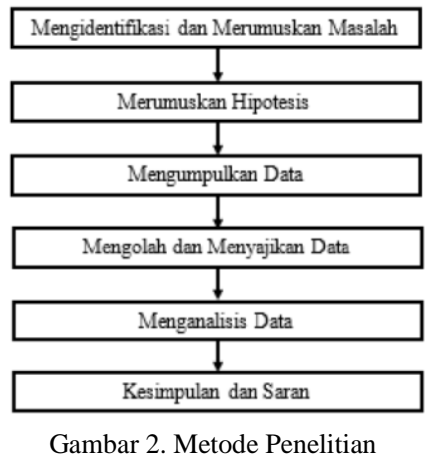

Berdasarkan hasil-hasil tahapan yang digambarkan diatas, agar peneliti lebih mudah memahami. Maka rincian penjelasan mengenai langkah-langkah yang digunakan oleh peneliti adalah sebagai berikut:

1. Mengidentifikasi dan Merumuskan Masalah

Peneliti mengidentifikasi dan merumuskan masalah dengan bentuk pertanyaan yang dijawab pada tujuan penelitian. Permasalahan yang diangkat pada penelitian ini adalah masalah yang berhubungan dengan judul penelitian ini yaitu analisis perilaku penggunaan OASIS (Online Academics Information System) menggunakan metode UTAUT 2. Merumuskan Hipotesis

Hipotesis dalam penelitian ini bersifat dugaan sementara terhadap objek penelitian perilaku pengguna aplikasi terhadap penggunaan aplikasi OASIS (Online Academics Information System), dimana hipotesis yang diambil dalam penelitian ini didasarkan pada penggunaan variabel seperti Ekspektasi Kinerja (Performance Expectancy), Ekspektasi Usaha (Effort Expectancy), Faktor Sosial (Social Influence), Kondisi-Kondisi Pemfasilitasi (Facilitating Condition), Motivasi Hedonis (Hedonic Motivation), Nilai Harga (Price Value), Kebiasaan (Habit) dan Perilaku Penggunaan (Use Behavior) yang terdapat dalam metode UTAUT 2.

3. Mengumpulkan Data

Peneliti mengumpulkan data untuk bahan pengolahan data penelitian berupa data primer dengan melakukan penyebaran Kuesioner yang terdiri dari beberapa pertanyaan yang berhubungan dengan variabel yang terkait dalam metode UTAUT 2 seperti Ekspektasi Kinerja (Performance Expectancy), Ekspektasi Usaha (Effort Expectancy), Faktor Sosial (Social Influence), Kondisi-Kondisi Pemfasilitasi (Facilitating Condition), Motivasi Hedonis (Hedonic Motivation), Nilai Harga (Price Value), Kebiasaan (Habit) dan Perilaku Penggunaan (Use Behavior) terhadap responden aplikasi OASIS (Online Academics Information System).

4. Mengolah dan Menyajikan Data

Langkah selanjutnya setelah mengumpulkan data adalah mengolah dan menyajikan data. Data yang telah terkumpul diolah sehingga menghasilkan informasi dari objek penelitian. Setelah data diolah maka peneliti menyajikan data atau menyusun data agar lebih teratur sehingga mudah dibaca, dipahami dan dianalisis.

5. Menganalisis Data

Dari hasil pengolahan data yang telah dilakukan maka data dianalisis lebih lanjut dengan menggunakan alat-alat analisis yang sesuai dengan tujuan riset agar menghasilkan kajian yang cukup akurat, mendalam dan luas. Hasil kajian ini dilengkapi dengan penjelasannya. Alat yang digunakan oleh peneliti adalah analisis deskriptif dan analisis statistik.

6. Kesimpulan dan Saran

Setelah peneliti melakukan analisis data terhadap objek penelitian, maka peneliti membuat kesimpulan dan saran. Dimana kesimpulan yang ditarik berdasarkan acuan hipotesis yang telah dibuat sebelumnya. Saran yang disajikan oleh peneliti karena penelitian yang dilakukan memiliki keterbatasan-keterbatasan atau asumsi-asumsi.

Dalam penelitian ini penulis menggunakan sebuah model sebagai kerangka pemikiran teoritis yaitu UTAUT 2 yang digunakan dalam OASIS. Sesuai dengan ruang lingkup penelitian maka model UTAUT 2 yang digunakan dalam penelitian ini telah dimodifikasi sedemikian rupa. Model penelitian tersebut memberikan gambaran bahwa ada pengaruh sejumlah faktor dari performance expectancy (PE), effort expectancy (EE), social influence (SI), facilitating conditions (FC), hedonic motivation (HM), nilai harga price value (PV), dan habit (HI) terhadap use behaviour (UB) yang selanjutnya akan dianalisis menggunakan software analisis SPSS. Seperti terlihat pada Gambar 3 


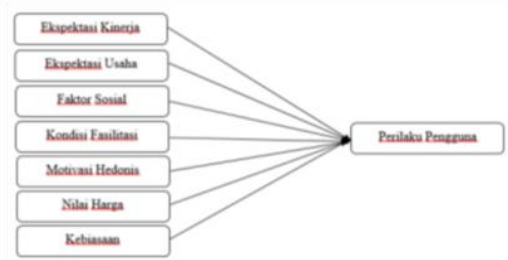

Gambar 3. Model Penelitian

Skala pengukuran dalam jawaban kuisioner yang akan digunakan pada penelitian ini adalah skala Likert, dimana variable yang akan diukur dijabarkan menjadi indikator variabel. Kemudian indikator tersebut dijadikan sebagai titik tolak untuk menyusun item-item instrument yang dapat berupa pernyataan atau pertanyaan. Untuk keperluan analisis kuantitatif, maka jawaban itu diberi skor 1-5 yang didefinisikan sebagai berikut:

Sangat Tidak Setuju (STS) diberi skor 1,

Tidak Setuju (TS) diberi skor 2,

Baik (B) diberi skor 3,

Setuju (S) diberi skor 4,

Sangat Setuju (SS) diberi skor 5

Hipotesis dalam penelitian ini meliputi hipotesis umum dan hipotesis khusus. Hipotesis umum pada penelitian ini adalah :

H 1 : Ekspektasi Kinerja (Performance Expectancy) berpengaruh signifikan positif terhadap Perilaku Penggunaan (Use Behavior).

H 2 : Ekspektasi Usaha (Effort Expectancy) berpengaruh signifikan positif terhadap Perilaku Penggunaan (Use Behavior).

H 3 : Faktor Sosial (Social Influence) berpengaruh signifikan positif terhadap Perilaku Penggunaan (Use Behavior).

H 4 : Kondisi-Kondisi Pemfasilitasi (Facilitating Condition) berpengaruh signifikan positif terhadap Perilaku Penggunaan (Use Behavior).

H 5 : Motivasi Hedonis (Hedonic Motivation) berpengaruh signifikan positif terhadap Perilaku Penggunaan (Use Behavior).

H 6 : Nilai Harga (Price Value) berpengaruh signifikan positif terhadap Perilaku Penggunaan (Use Behavior).

H 7 : Kebiasaan (Habit) berpengaruh signifikan positif terhadap Perilaku Penggunaan (Use Behavior).

H 8 : $\quad$ Ekspektasi Kinerja (Performance Expectancy), Ekspektasi Usaha (Effort Expectancy), Faktor Sosial (Social Influence), Kondisi-Kondisi Pemfasilitasi (Facilitating Condition), Motivasi Hedonis (Hedonic Motivation), Nilai Harga (Price Value), Kebiasaan (Habit) secara bersama-sama berpengaruh signifikan positif terhadap Perilaku Penggunaan (Use Behavior).

Untuk melakukan analisis data dengan menggunakan teknik Analisis SPSS maka tools yang digunakan dalam penelitian ini adalah Software SPSS 25.

\section{HASIL DAN PEMBAHASAN}

Berikut ini merupakan hasil penerpan OASIS dengan menggunakan metode UTAUT 2.

1. Hasil

a. Uji Validitas

Uji validitas yang digunakan dalam penelitian ini yaitu dengan menggunakan rumus korelasi bivariate pearson dengan alat bantu aplikasi SPSS 25. Ketentuan hasil akhir apabila $r$ hitung $>r$ tabel maka item pertanyaan dikatakan valid. Nilai $r$ tabel dari penelitian dengan jumlah responden 100 orang dengan signifikasi 5\% memiliki nilai sebesar 0,195 (www.spssindonesia.com, 2019). Pengujian validitas dapat dilihat pada tabel dibawah ini: 
TABEL I

HASIL UJI VALIDITAS

\begin{tabular}{|c|c|c|c|c|}
\hline Variabel & Indikator & $r$ hitung & $r$ tabel $5 \%(100)$ & Keterangan \\
\hline \multirow{4}{*}{$\begin{array}{c}\text { Ekspeltasi } \\
\text { Kinerja } \\
\text { (Performance } \\
\text { Expectancy) }\end{array}$} & PE.1 & 0,735 & 0,195 & Valid \\
\hline & PE. 2 & 0.816 & 0,195 & Valid \\
\hline & PE. 3 & 0,855 & 0,195 & Valid \\
\hline & PE.4 & 0.876 & 0,195 & Valid \\
\hline \multirow{3}{*}{$\begin{array}{c}\text { Ekspeltasi Usaha } \\
\text { (Effort } \\
\text { Expectancy) }\end{array}$} & EE. 1 & 0,848 & 0,195 & $\begin{array}{l}\text { Valid } \\
\end{array}$ \\
\hline & EE. 2 & 0.849 & 0,195 & Valid \\
\hline & EE. 3 & 0,805 & 0,195 & Valid \\
\hline \multirow{3}{*}{$\begin{array}{c}\text { Faktor Sosial } \\
\text { (Social Influence) }\end{array}$} & SI.1. & 0.856 & 0,195 & Valid \\
\hline & SI.2 & 0,872 & 0,195 & Valid \\
\hline & SI. 3 & 0.754 & 0,195 & Valid \\
\hline \multirow{3}{*}{$\begin{array}{c}\text { Kondisi-Kondisi } \\
\text { Pemfasilitasi } \\
\text { (Facilitating } \\
\text { Condition) } \\
\end{array}$} & FC.1 & 0,807 & 0,195 & Valid \\
\hline & FC. 2 & 0.773 & 0,195 & Valid \\
\hline & $\mathrm{FC} .3$ & 0,723 & 0,195 & Valid \\
\hline \multirow{3}{*}{$\begin{array}{c}\text { Motivasi Hedonis } \\
\text { (Hedonic } \\
\text { Motivation) }\end{array}$} & HM.1 & 0,764 & 0,195 & Valid \\
\hline & HM.2 & 0.856 & 0,195 & Valid \\
\hline & HM. 3 & 0.852 & 0,195 & Valid \\
\hline \multirow{3}{*}{$\begin{array}{l}\text { Nilai Harga } \\
\text { (Price Value) }\end{array}$} & PV.1 & 0.876 & 0,195 & Valid \\
\hline & PV.2 & 0,888 & 0,195 & Valid \\
\hline & PV. 3 & 0.829 & 0,195 & Valid \\
\hline \multirow{3}{*}{$\begin{array}{c}\text { Kebiasaan } \\
\text { (Habit) }\end{array}$} & HI. 1 & 0,734 & 0,195 & Valid \\
\hline & HI. 2 & 0.831 & 0,195 & Valid \\
\hline & HI. 3 & 0,727 & 0,195 & Valid \\
\hline \multirow{4}{*}{$\begin{array}{c}\text { Perilaku } \\
\text { Penggunaan (Use } \\
\text { Behavior) }\end{array}$} & UB. 1 & 0.696 & 0,195 & Valid \\
\hline & UB. 2 & 0,652 & 0,195 & Valid \\
\hline & UB. 3 & 0.456 & 0,195 & Valid \\
\hline & & & 0,195 & $\begin{array}{l}\text { Valid } \\
\end{array}$ \\
\hline
\end{tabular}

Dari hasil pengolahan data terhadap uji validitas indikator-indikator pertanyaan yang telah dilakukan maka dapat ditarik kesimpulan terhadap penelitian bahwa semua butir pernyataan yang diberikan terhadap responden dalam penerapan model UTAUT 2 untuk memahami perilaku penggunaan OASIS di Sekolah Tinggi Teknologi Bandung dinyatakan valid dan layak dijadikan sebagai data pengambilan sampel penelitian karena hasil dari $r$ hitung lebih besar dari pada $\mathrm{r}$ tabel.

\section{b. Uji Reliabilitas}

Uji Reliabilitas digunakan untuk mengetahui reliabel atau tidaknya pernyataan di dalam kuesioner, sehingga jawaban responden terhadap pernyataan tersebut menjadi konsisten atau stabil. Pengujian reliabilitas dilakukan dengan melihat nilai Cronbach Alpha pada tabel Reliability Statistic yang sudah diolah menggunakan SPSS 25. Pengujian reliablilitas dapat dilihat pada tabel 2

TABEL II

HASIL UJI RELIABILITAS

\begin{tabular}{|c|c|c|c|}
\hline Variabel & Cronbach Alpha & rtabel 5\% $(\mathbf{1 0 0 )}$ & Keterangan \\
\hline PE & 0,836 & 0,195 & Reliabel \\
\hline EE & 0,778 & 0,195 & Reliabel \\
\hline SI & 0,772 & 0,195 & Reliabel \\
\hline FC & 0,628 & 0,195 & Reliabel \\
\hline HM & 0,764 & 0,195 & Reliabel \\
\hline PV & 0,830 & 0,195 & Reliabel \\
\hline HI & 0,609 & 0,195 & Reliabel \\
\hline BI & 0,357 & 0,195 & Reliabel \\
\hline
\end{tabular}

Dari hasil data yang telah diolah dengan menggunakan aplikasi SPSS terhadap variabel ekspektasi kinerja, ekspektasi usaha, faktor sosial, kondisi-kondisi pemfasilitas serta niat perilaku cronbach's alpha per-item memiliki nilai sebagai berikut $\mathrm{PE}=0,836 ; \mathrm{EE}=0,778 ; \mathrm{SI}=0,772 ; \mathrm{FC}=0,628 ; \mathrm{HM}=0,764 ; \mathrm{PV}=0,830 ; \mathrm{HI}=$ 0,609 serta $\mathrm{BI}=0,357$ maka variabel UTAUT 2 yang digunakan dalam penelitian ini dinyatakan memenuhi uji Reliabilitas atau reliabel.

\section{c. Uji T}

Uji t atau uji parsial yaitu untuk menguji bagaimana pengaruh masing-masing variabel bebas terhadap variabel terikat dalam penelitian. Uji ini dapat dilakukan dengan mambandingkan $t$ hitung dengan t tabel atau dengan melihat kolom signifikansi pada masing-masing t hitung. Ketentuan dalam pengambilan uji t sebagai berikut:

1. Jika nilai sig $<0,05$ atau $\mathrm{t}$ hitung $>\mathrm{t}$ tabel maka terdapat pengaruh variabel $\mathrm{X}$ terhadap variabel $\mathrm{Y}$.

2. Jika nilai sig $>0,05$ atau $t$ hitung $<\mathrm{t}$ tabel maka tidak terdapat pengaruh variabel $\mathrm{X}$ terhadap variabel $\mathrm{Y}$.

Nilai t tabel yang terdapat dalam distribusi nilai $r$ tabel product moment dengan signifikasi 5\% sebesar 1988 (www.spssindonesia.com).

Perhitungan t tabel dari penelitian seperti dibawah ini:

$\mathrm{t}$ tabel $=\mathrm{t}(\alpha / 2 ; \mathrm{n}-\mathrm{k}-1)$

$\mathrm{t}$ tabel $=\mathrm{t}(0,05 / 2 ; 100-7-1)$

$\mathrm{t}$ tabel $=\mathrm{t}(0,025 ; 92)$

$\mathrm{t}$ tabel $=1,989$ 


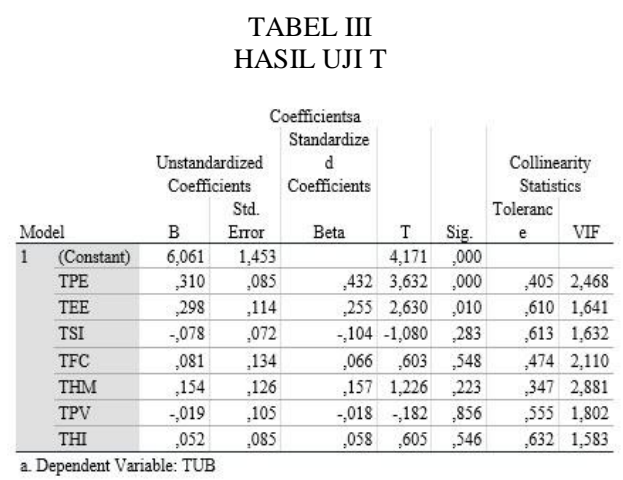

Berdasarkan tabel 3 setiap variabel yang digunakan dalam penelitian ini meniliki nilai sig seperti $(\mathrm{PE})=$ $0,000,(\mathrm{EE})=0,010,(\mathrm{SI})=0,283,(\mathrm{FC})=0,548,(\mathrm{HM})=0,223,(\mathrm{PV})=0,856,(\mathrm{HI})=0,546$ dan nilai $\mathrm{t}$ masing masing variabel yaitu $(\mathrm{PE})=3,632,(\mathrm{EE})=2,630,(\mathrm{SI})=-1,080,(\mathrm{FC})=0,603,(\mathrm{HM})=1,226,(\mathrm{PV})=-0,182$, $(\mathrm{HI})=0,605$.

d. $\quad$ Uji F terikat.

Uji f digunakan untuk menguji bagaimana pengaruh semua variabel bebas secara simultan terhadap variabel

Ketentuan dalam pengambilan keputusan terhadap uji f yaitu:

1. Jika nilai sig $<0,05$ atau $\mathrm{f}$ hitung $>\mathrm{f}$ tabel maka terdapat pengaruh variabel $\mathrm{X}$ terhadap variabel $\mathrm{Y}$.

2. Jika nilai sig $>0,05$ atau $\mathrm{f}$ hitung $<\mathrm{f}$ tabel maka tidak terdapat pengaruh variabel $\mathrm{X}$ terhadap variabel $\mathrm{Y}$.

Nilai $f$ tabel yang terdapat dalam distribusi nilai f tabel product moment dengan signifikasi $5 \%$ sebesar 2,46 (www.spssindonesia.com).

Perhitungan $\mathrm{f}$ tabel dari penelitian seperti dibawah ini:

$\mathrm{f}$ tabel $=\mathrm{f}(\mathrm{k} ; \mathrm{n}-\mathrm{k})$

$\mathrm{f}$ tabel $=\mathrm{f}(7 ; 100-7)$

$\mathrm{f}$ tabel $=\mathrm{f}(7 ; 93)=2,10$

TABEL 4

HASIL UJI F

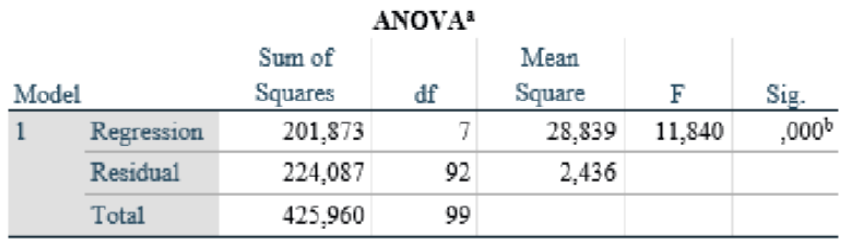

a. Dependent Variable: TUB

b. Predictors: (Constant), THI, TEE, TSI, TPV, TFC, TPE, THM

Prosedur pengujian hipotesis uji $\mathrm{F}$ adalah sebagai berikut:

1. Perumusan Hipotesis Operasional (H0) dan Hipotesis Alternatif (Ha)

H0: UTAUT 2 tidak berpengaruh secara simultan terhadap OASIS

Ha: UTAUT 2 berpengaruh secara simultan terhadap OASIS

2. Kriteria penerimaan atau penolakan hipotesis $\mathrm{H} 0$ diterima jika nilai $\mathrm{F}$ hitung $<2,10$

$\mathrm{H} 0$ ditolak jika nilai $\mathrm{F}$ hitung $\geqslant 2,10$

3. Penarikan kesimpulan

Berdasarkan Tabel 4, untuk variabel UTAUT 2 diperoleh nilai F hitung sebesar 11,840 $\geqslant 2,10$ maka H0 ditolak. Oleh karena itu, dapat disimpulkan bahwa UTAUT 2 berpengaruh secara simultan terhadap perilaku pengguna OASIS. Berdasarkan hasil uji f diperoleh nilai F 11,840 dengan nilai sig 0,000 variabel Ekspektasi Kinerja (Performance Expectancy), Ekspektasi Usaha (Effort Expectancy), Faktor Sosial (Social Influence), Kondisi-Kondisi Pemfasilitasi (Facilitating Condition), Motivasi Hedonis (Hedonic Motivation), Nilai Harga (Price Value), Kebiasaan (Habit) secara bersama-sama atau simultan berpengaruh terhadap Perilaku Penggunaan (Use Behavior). 
e. Uji Koefisien Determinasi

Koefisien determinasi (R2) bertujuan untuk mengetahui besarnya sumbangan atau kontribusi dari variabel bebas terhadap variabel terikat pada model UTAUT 2. Koefisien determinasi berguna untuk menunjukan seberapa besar pengaruh variabel bebas memiliki pengaruh terhadap variabel terikatnya.

$$
\text { TABEL } 5
$$

UJI KOFISIEN DETERMINASI

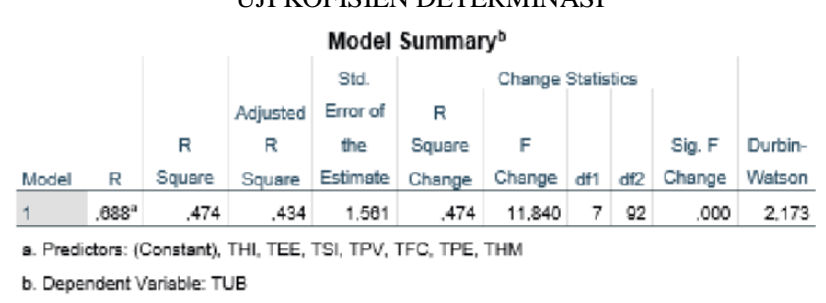

Berdasarkan hasil tabel 5 maka nilai koefisien determinasi R2 sebesar 0,474 atau 47,4\%. Jadi pengaruh dari 7 variabel bebas terhadap variabel terkait sebesar 0,474 atau $47,4 \%$. Sedangkan nilai yang tersisa yaitu sebesar $52,6 \%$ dipengaruhi oleh faktor-faktor lain yang tidak diteliti pada penelitian ini.

2. Pembahasan

Setelah menguji model yang digunakan terhadap uji validitas, uji Reliabilitas, uji asumsi klasik dan uji menggunakan model regreasi linear berganda seperti: uji koefisien determinasi, uji t, uji f serta menguji hipotesis dari penelitian tahap selanjutnya adalah pembahasan hasil penelitian.

a. Analisis pengaruh Ekspektasi Kinerja (Performance Expectancy) berpengaruh terhadap Perilaku Penggunaan (Use Behavior)

Dari hasil penelitian ini diketahui bahwa variabel Ekspektasi Kinerja (Performance Expectancy) itu memiliki hubungan yang signifikan terhadap Perilaku Penggunaan (Use Behavior) tingkat hubungan dengan nilai t hitung sebesar 3,632 dan nilai signifikasi dari ekspektasi kinerja $(\mathrm{PE})=0,000$. Sehingga semakin Setuju variabel Ekspektasi Kinerja (Performance Expectancy) maka dapat meningkatkan Perilaku Penggunaan (Use Behavior) terhadap Penerapan Model UTAUT 2 Untuk Memahami Perilaku Penggunaan OASIS di Sekolah Tinggi Teknologi Bandung.

b. Analisis pengaruh Ekspektasi Usaha (Effort Expectancy) berpengaruh terhadap Perilaku Penggunaan (Use Behavior)

Dari hasil penelitian ini diketahui bahwa variabel Ekspektasi Usaha (Effort Expectancy) itu memiliki hubungan yang signifikan terhadap Perilaku Pengguna tingkat hubungan dengan nilai t hitung sebesar 2,630 dan nilai signifikasi dari ekspektasi usaha $(E E)=0,010$. Sehingga semakin Setuju variabel Ekspektasi Usaha (Effort Expectancy) maka dapat meningkatkan Perilaku Pengguna terhadap Penerapan Model UTAUT 2 Untuk Memahami Perilaku Penggunaan OASIS di Sekolah Tinggi Teknologi Bandung.

c. Analisis pengaruh Faktor Sosial (Social Influence) tidak berpengaruh terhadap Perilaku Penggunaan (Use Behavior)

Dari hasil penelitian ini diketahui bahwa variabel Faktor Sosial (Social Influence) itu tidak memiliki hubungan yang signifikan terhadap Perilaku Penggunaan (Use Behavior) tingkat hubungan dengan nilai t hitung sebesar -1.080 dan nilai signifikasi dari faktor sosial $(\mathrm{SI})=0,283$. Sehingga tidak Setuju variabel Faktor Sosial (Social Influence) maka dapat meningkatkan Perilaku Penggunaan (Use Behavior) terhadap Penerapan Model UTAUT 2 Untuk Memahami Perilaku Penggunaan OASIS di Sekolah Tinggi Teknologi Bandung.

d. Analisis pengaruh Kondisi-Kondisi Pemfasilitasi (Facilitating Condition) tidak berpengaruh terhadap Perilaku Penggunaan (Use Behavior)

Dari hasil penelitian ini diketahui bahwa variabel Kondisi-Kondisi Pemfasilitasi (Facilitating Condition) itu tidak memiliki hubungan yang signifikan terhadap Perilaku Penggunaan (Use Behavior) tingkat hubungan dengan nilai thitung sebesar 0,603 dan nilai signifikasi dari kondisi-kondisi pemfasilitas (FC) $=0,548$. Sehingga tidak Setuju variabel Kondisi Pemfasilitasi (Facilitating Condition) maka dapat meningkatkan Perilaku Penggunaan (Use Behavior) terhadap Penerapan Model UTAUT 2 Untuk Memahami Perilaku Penggunaan OASIS di Sekolah Tinggi Teknologi Bandung.

e. Analisis pengaruh Motivasi Hedonis (Hedonic Motivation) tidak berpengaruh terhadap Perilaku Penggunaan (Use Behavior)

Dari hasil penelitian ini diketahui bahwa variabel Motivasi Hedonis (Hedonic Motivation) itu tidak memiliki hubungan yang signifikan terhadap Perilaku Penggunaan (Use Behavior) tingkat hubungan dengan nilai t hitung sebesar 1,226 dan nilai signifikasi dari Motivasi Hedonis (Hedonic Motivation) $=0,223$. Sehingga tidak Setuju 
variabel Motivasi Hedonis (Hedonic Motivation) dapat meningkatkan Perilaku Penggunaan (Use Behavior) terhadap Penerapan Model UTAUT 2 Untuk Memahami Perilaku Penggunaan OASIS di Sekolah Tinggi Teknologi Bandung.

f. Analisis pengaruh Nilai Harga (Price Value) tidak berpengaruh terhadap Perilaku Penggunaan (Use Behavior)

Dari hasil penelitian ini diketahui bahwa variabel Nilai Harga (Price Value) itu tidak memiliki hubungan yang signifikan terhadap Perilaku Penggunaan (Use Behavior) tingkat hubungan dengan nilai t hitung sebesar 0,182 dan nilai signifikasi dari Nilai Harga (Price Value) $=0,856$. Sehingga tidak Setuju variabel Nilai Harga (Price Value) dapat meningkatkan Perilaku Penggunaan (Use Behavior) terhadap Penerapan Model UTAUT 2 Untuk Memahami Perilaku Penggunaan OASIS di Sekolah Tinggi Teknologi Bandung.

g. Analisis pengaruh Kebiasaan (Habit) tidak berpengaruh terhadap Perilaku Penggunaan (Use Behavior)

Dari hasil penelitian ini diketahui bahwa variabel Kebiasaan (Habit) itu tidak memiliki hubungan yang signifikan terhadap Perilaku Penggunaan (Use Behavior) tingkat hubungan dengan nilai t hitung sebesar 0,605 dan nilai signifikasi dari Kebiasaan $($ Habit $)=0,546$. Sehingga tidak Setuju variabel Kebiasaan (Habit) dapat meningkatkan Perilaku Penggunaan (Use Behavior) terhadap Penerapan Model UTAUT 2 Untuk Memahami Perilaku Penggunaan OASIS di Sekolah Tinggi Teknologi Bandung.

h. Analisis pengaruh ekspektasi Kinerja (Performance Expectancy), Ekspektasi Usaha (Effort Expectancy), Faktor Sosial (Social Influence), Kondisi-Kondisi Pemfasilitasi (Facilitating Condition), Motivasi Hedonis (Hedonic Motivation), Nilai Harga (Price Value), Kebiasaan (Habit) berpengaruh terhadap Perilaku Penggunaan (Use Behavior)

Dari hasil penelitian ini diketahui bahwa variabel ekspektasi Kinerja (Performance Expectancy), Ekspektasi Usaha (Effort Expectancy), Faktor Sosial (Social Influence), Kondisi-Kondisi Pemfasilitasi (Facilitating Condition), Motivasi Hedonis (Hedonic Motivation), Nilai Harga (Price Value), Kebiasaan (Habit) secara bersama-sama atau simultan itu memiliki hubungan yang signifikan terhadap Perilaku Penggunaan (Use Behavior) tingkat hubungan dengan nilai f hitung 11,840 dengan nilai sig 0,000 dan nilai R Square 0,474 tingkat pengaruh variabel $\mathrm{X}$ terhadap variabel $\mathrm{Y}$ sebesar $47,4 \%$.

\section{KESIMPULAN}

Berdasarkan hasil penelitian dan pembahasan mengenai penerapan metode UTAUT 2 (Unified Theory of Acceptance and Use of Technology 2) dalam memahami penerimaan OASIS, maka dapat beberapa kesimpulan sebagai berikut dari hasil penelitian dengan menggunakan model UTAUT 2 untuk mengukur tingkat penerimaan OASIS menunjukkan bahwa

1. Ekspektasi Kinerja (Performance Expectancy) berpengaruh terhadap Perilaku Penggunaan (Use Behavior). Hal tersebut dikarenakan OASIS membantu proses pembelajaran dan meningkatkan kinerja serta produktivitas mahasiswa-mahasiswi di Sekolah Tinggi Teknologi Bandung.

2. Ekspektasi Usaha (Effort Expectancy) berpengaruh terhadap Perilaku Penggunaan (Use Behavior). Hal tersebut dikarenakan adanya pemahaman terhadap penggunaan OASIS di Sekolah Tinggi Teknologi Bandung.

3. Faktor Sosial (Social Influence) tidak berpengaruh terhadap Perilaku Penggunaan (Use Behavior). Hal tersebut dikarenakan mahasiswa-mahasiswi merasakan bahwa masih kurangnya dorongan menggunakan OASIS yang ada di Sekolah Tinggi Teknologi Bandung.

4. Kondisi-Kondisi Pemfasilitasi (Facilitating Condition) tidak berpengaruh terhadap Perilaku Penggunaan (Use Behavior). Hal tersebut dikarenakan mahasiswa-mahasiswi meyakini bahwa infrastruktur organisasi dan teknis yang ada belum mendukung penggunaan OASIS di Sekolah Tinggi Teknologi Bandung.

5. Motivasi Hedonis (Hedonic Motivation) tidak berpengaruh terhadap Perilaku Penggunaan (Use Behavior). Hal tersebut dikarenakan mahasiswa-mahasiswi merasakan bahwa kurangnya kesenangan dalam menggunakan OASIS di Sekolah Tinggi Teknologi Bandung

6. Nilai Harga (Price Value) tidak berpengaruh terhadap Perilaku Penggunaan (Use Behavior). Hal tersebut dikarenakan mahasiswa-mahasiswi merasakan bahwa kurangnya nilai harga dalam menggunakan OASIS di Sekolah Tinggi Teknologi Bandung

7. Kebiasaan (Habit) tidak berpengaruh terhadap Perilaku Penggunaan (Use Behavior). Hal tersebut dikarenakan mahasiswamahasiswi merasakan bahwa bukan lagi menjadi kebiasaan namun sebuah keharusan menggunakan OASIS di Sekolah Tinggi Teknologi Bandung.

8. Ekspektasi Kinerja (Performance Expectancy), Ekspektasi Usaha (Effort Expectancy), Faktor Sosial (Social Influence), Kondisi-Kondisi Pemfasilitasi (Facilitating Condition), Motivasi Hedonis (Hedonic Motivation), Nilai Harga (Price Value), Kebiasaan (Habit) secara bersama-sama atau simultan itu memiliki hubungan yang signifikan terhadap Perilaku Pengguna (Use Behavior). 


\section{REFERENSI}

[1] Anggraini, Siska, M. Haviz Irfani, Sri Rahayu. 2020. Analisis Penerimaan Sistem Informasi Akademik Dengan Menggunakan UTAUT 2 (Studi Kasus: Akademi Keperawatan Pembina Palembang).JUSIFO, 15-30.

[2] Dewi, Citra, Irma Salamah, dan Lindawati. 2018. Penerapan Model UTAUT Untuk Pemahaman Sistem Informasi Akademik Di Politeknik Negeri Sriwijaya. SENTIKA, 216-224.

[3] Jundullah, Muhammad, Rusydi Umar, Anton Yudhana. 2021. Pengaruh Persepsi Kemanfaatan dan Kemudahan Penggunaan Terhadap Penerimaan Sistem E-Learning Di SMK Negeri 4 Kota Sorong. Bina Insani ICT Journal, 12-21.

[4] Juningsih, Eka Herdit, Faruq Aziz, Dinar Ismunandar, Fajar Sarasati, Irmawati, Yanto. 2020. Penggunaan Model UTAUT2 Untuk Memahami Persepsi Pengguna Aplikasi G-Meet. IJSE. 289-295

[5] Ndarbeni, Ana Wati, Wing Wahyu Winarno, Andi Sunyoto. 2016. Analisis Penerapan Sistem Informasi Akademik STIKES Muhammadiyah Gombong. Jurnal IT CIDA. 1-13

[6] Maulidah, Mawadatul, Toni Arifin, Abdurahman Fauzi. 2019. Analisis Perilaku Siswa SMK Negeri 1 Dukuhturi Terhadap Penggunaan Edmodo Menggunakan UTAUT

[7] Mediyanto, Beni, Irfan Mahendra. 2017. Penerapan Metode Utaut Untuk Memprediksi Behavioral Intentions User Dalam Menggunakan Aplikasi Zabbix. Jurnal Ilmu Pengetahuan dan Teknologi Komputer, 9-16

[8] Onilaba, Anggreiny A, Yaulie Rindengan, Arie S. Lumenta, 2021. Analisis Penerapan Model UTAUT 2 (UNIFIED THEORY OF ACCEPTANCE AND USE OF TECHNOLOGY 2) Terhadap E-Kinerja Pada Pemerintah Provinsi Sulawesi Utara. E-journal Teknik

[9] Informatika, 1-12

[10]Prasetyo, Dwi Yuli. 2017. Penerapan Metode Utaut (Unified Theory Of Acceptance And Use Of Technology) Dalam Memahami Penerimaan Dan Penggunaan Website Kkn Lppm Unisi. Jurnal SISTEMASI Volume 6, 26-34

[11]Prihandoyo, M., Teguh. 2018. Unified Modeling Language (UML) Model Untuk Pengembangan Sistem Informasi Akademik Berbasis Web. Jurnal Informatika: Jurnal Pengembangan IT (JPIT), Vol.03, No.01, 126-129.

[12] Sabarkhah, Dwi Rizki. 2018. PENGUKURAN TINGKAT PENERIMAAN DAN PENGGUNAAN TEKNOLOGI UANG ELEKRONIK DI TANGERANG SELATAN DENGAN MENGGUNAKAN METODE UTAUT 2.

[13] Sitanggang, Ns. Morlina, Jawa Bendi, dan Soejono. 2017. Analisis Perilaku Penggunaan Sistem Informasi Akademik Oleh Mahasiswa Keperawatan, Jurnal Sistem \& Teknologi Informasi Komunikasi, Vol. 1, No. 1, 1-12.

[14] Sutanto, Imam Ghozali, dan Handayani, Rr. Sri. 2018. Faktor-Faktor Yang Memengaruhi Penerimaan dan Penggunaan Sistem Informasi Pengelolaan Keuangan Daerah (SIPKD) Dalam Perspektif The Unified Theory of Acceptance and Use of Technology 2 (UTAUT 2) Di Kabupaten Semarang, Jurnal Akuntansi dan Auditing, Volume 15, No. 1, 37-68. 